\title{
Perbedaan Efek Kompres Selimut Basah dan Cold-pack terhadap Suhu Tubuh Pasien Cedera Kepala di Neurosurgical Critical Care Unit
}

\author{
Sri Hartati Pratiwi ${ }^{1}$, Helwiyah Ropi ${ }^{1}$, Ria Sitorus ${ }^{2}$ \\ ${ }^{1}$ Fakultas Keperawatan, Universitas Padjadjaran, ${ }^{2} \mathrm{RSHS}$ \\ Email: srihartatipratiwi86@gmail.com
}

\begin{abstract}
Abstrak
Peningkatan suhu tubuh pada pasien cedera kepala bisa menyebabkan peningkatan metabolisme yang dapat memperburuk kondisi pasien, meningkatkan lama hari rawat dan menambah resiko kematian. Metode pendinginan yang sering digunakan adalah kompres selimut basah dan cold-pack. Namun belum ada penelitian yang membuktikan efek kedua metoda tersebut terhadap suhu tubuh pasien cedera kepala. Penelitian ini menggunakan rancangan perbandingan tidak berpasangan. Teknik pengambilan sampel yang digunakan adalah consecutive sampling dengan jumlah 24 orang responden. Penelitian ini memberikan hasil tidak terdapat perbedaan yang signifikan antara penurunan suhu tubuh setelah kompres selimut basah dan setelah kompres cold-pack $(\mathrm{p}=0,371)$. Oleh karena itu, kompres cold-pack dapat dijadikan alternatif kompres selimut basah yang biasa digunakan.
\end{abstract}

Kata kunci : Cold-pack, cedera kepala, selimut basah, suhu tubuh.

\section{Wet Blanket and Cold-pack Application to Reduce Body Temperature among Patients with Head Injury in Neurosurgical Critical Care Unit}

\begin{abstract}
The elevation of body temperature among patients with head injury may lead to increase total metabolism of the body. Such situation may worsen the patient condition, prolonged length of stay and increase risk of death. Cooling methods using wet blanket and cold-pack have been commonly adopted to reduce the body heat. However no empirical studies have proved these methods are effective to reduce high temperature of patients with head injury. This non-paired comparative study seeks to examine the difference of those two methods towards body temperature involving 24 patients with head injury that recruited using consecutive sampling technique. Results indicated that there is no significant difference of the temperature decrease after wet blanket and cold-pack application $(\mathrm{p}=0,371)$. However, cold-pack still can be used as an alternative compress beside wet blanket application.
\end{abstract}

Key words: Cold-pack, head injury, body temperature, wet blanket. 
Sri Hartati: Perbedaan Efek Kompres Selimut Basah dan Cold-pack

\section{Pendahuluan}

Kejadian cedera kepala dan trauma tulang belakang di Indonesia mencapai 7,5\% dari populasi (Badan Penelitian dan Pengembangan Kesehatan Departemen Kesehatan Republik Indonesia, 2007). Angka kejadian cedera kepala di Rumah Sakit Umum Pusat Dr. Hasan Sadikin (RSHS) pada tahun 2010 sebanyak 1378 kasus dan pada tahun 2011 sebanyak 1095 kasus (rekam medik RSHS, 2011). Hal ini memperlihatkan bahwa angka kejadian cedera kepala di Jawa Barat masih tinggi. Cedera kepala dapat menimbulkan berbagai gangguan mental, fisik bahkan kematian. Menurut Werner dan Engelhard (2007), cedera kepala merupakan penyebab kematian dan kesakitan terbesar di dunia pada usia dibawah 45 tahun sehingga memerlukan perhatian yang besar dari kalangan petugas kesehatan.

Kerusakan bagian otak pada pasien cedera kepala dapat menyebabkan peningkatan suhu tubuh (Muttaqin, 2008). Peningkatan suhu tubuh sangat umum terjadi pada pasien cedera kepala. Hal ini diakibatkan adanya gangguan pada set point di hipotalamus (Agrawal, Timothy, \& Thapa, 2007). Selain itu, peningkatan suhu pada pasien cedera kepala juga bisa disebabkan oleh inflamasi otak, kerusakan hipotalamus secara langsung, atau infeksi sekunder. Prevalensi peningkatan suhu tubuh pada pasien cedera kepala sebesar $68 \%$ terjadi pada 72 jam pertama, dan mencapai peningkatan suhu sebesar 2,10C (Thompson, Tkacs, Saatman, Raghupathi, \& McIntosh, 2003).

Pasien cedera kepala yang mengalami peningkatan suhu tubuh dapat mengalami perburukan. Hal ini didukung oleh penelitian yang dilakukan oleh Dietrich dalam Thompson, Tkacs, Saatman, Raghupathi, dan McIntosh (2003) yang menyatakan bahwa jika dibandingkan dengan pasien cedera kepala dengan suhu tubuh normal, pasien yang mengalami peningkatan suhu tubuh akan memiliki resiko kematian yang lebih besar. Selain itu, volume contusio cerebri akan bertambah dalam 4 hari pertama. Sejalan dengan penelitian tersebut, Diringer, Reaven, Funk, dan Uman (2004) mengungkapkan bahwa pasien cedera kepala yang mengalami peningkatan suhu tubuh memiliki tekanan intrakranial yang lebih tinggi dan angka mortalitas $78 \%$ serta hari rawat yang lebih lama dibandingkan dengan pasien normotermia. Berdasarkan penelitian yang dilakukan oleh Geffroy, Bronchard, Merckx, Seince, Faillot, Albaladejo et al. (2003) lamanya peningkatan suhu tubuh pasien tergantung pada derajat keparahan cedera kepala yang dialaminya.

Oleh karena itu, untuk mencegah perburukan kondisi akibat peningkatan suhu tubuh yang banyak dialami pasien cedera kepala, petugas kesehatan harus menjaga suhu tubuh pasien agar tetap normal (Mcilvoy, 2007). Terdapat beberapa metode dalam menangani peningkatan suhu tubuh yaitu manajemen farmakologis dan non farmakologis. Metode non farmakologis untuk menangani peningkatan suhu tubuh dapat dilakukan dengan metode pendinginan baik dari dalam maupun luar.

Pendinginan dari dalam dapat dilakukan dengan cara pemberian cairan dingin melalui intravena. Berdasarkan penelitian yang dilakukan oleh Larrson, Wallin, dan Rubertsson (2010), infus dingin memiliki efek yang cepat dalam mendinginkan suhu tubuh pasien tetapi tidak stabil. Oleh karena itu, dalam melaksanakan metoda ini membutuhkan kontrol yang ketat dari perawat. Metoda pendinginan dari dalam lain adalah penggunaan intravaskuler line dan pemberian oksigen melalui nasal cavitis. Prosedur intravascular line dilakukan dengan menggunakan Cool gard dan cool line catheter. Namun metoda ini hanya dapat dilakukan pada pasien yang terintubasi (Khorooshi \& Jensen, 1999).

Metode pendinginan dari luar yang biasa digunakan adalah penggunaan selimut dingin. Namun metoda ini memerlukan biaya yang cukup besar, sehingga jarang digunakan. Metoda pendinginan luar lain yang banyak dilakukan adalah penggunaan ice-pack dan cold-pack. Kompres es dan kompres air dingin merupakan salah satu metoda kompres yang banyak digunakan (Thompson, Mitchell, \& Webb, 2007). Dalam pelaksanaannya kedua metode ini dapat menyebabkan tubuh pasien menjadi basah sehingga mengganggu kenyamanannya. Oleh karena itu, beberapa tahun yang lalu telah dikembangkan cold-pack instan yang terbuat dari gel ammonium nitrat. 
Sri Hartati: Perbedaan Efek Kompres Selimut Basah dan Cold-pack

Selain dapat menurunkan nyeri, kompres dengan menggunakan cold-pack instan dapat digunakan untuk menurunkan suhu tubuh. Jika dibandingkan dengan metoda lain, penggunaan cold-pack lebih nyaman, murah, dan mudah dilakukan. Namun, penelitian mengenai efektivitas metoda tersebut dalam menurunkan suhu tubuh pasien cedera kepala masih terbatas.

Peningkatan suhu tubuh merupakan salah satu gangguan kebutuhan dasar yang sering dialami pasien. Perawat bertanggung jawab mengidentifikasi pasien yang mengalami peningkatan suhu tubuh, membuat rencana asuhan keperawatan, mengimplementasikan dan mengevaluasinya. Perawat harus memperhatikan keamanan dan kenyamanan pasien. Selain itu pemberian metoda pendinginan yang diberikan harus efektif dan mudah dilakukan sehingga tidak memperberat beban kerja perawat. Pada tatanan keperawatan kritis, pemberian metoda pendinginan sangat penting. Hal ini berkaitan dengan besarnya pengaruh peningkatan suhu tubuh terhadap peluang kesembuhan dan meningkatnya resiko kematian pasien (Thompson, Tkacs, Saatman, Raghupathi, \& McIntosh, 2003).

Berdasarkan studi pendahuluan, di Neurosurgical Critical Care Unit (NCCU) RSHS terdapat 4 orang pasien cedera kepala. 3 diantaranya mengalami peningkatan suhu tubuh.. Tindakan yang dilakukan perawat adalah mengompres dengan menggunakan handuk basah yang diselimutkan diatas dada dan perut pasien yang biasa disebut selimut basah. Dengan menggunakan metoda ini, suhu tubuh pasien menurun namun dalam waktu yang lama. Berdasarkan komunikasi personal dengan salah satu perawat, di ruang NCCU belum ada standar prosedur operasional (SPO) mengenai penanganan peningkatan suhu tubuh pada pasien. Metoda pendinginan lain belum dilakukan di ruangan NCCU (Oded, 2012).

Melihat kondisi yang telah dipaparkan sebelumnya bahwa hanya metoda selimut basah yang biasa dilakukan di NCCU, padahal masih ada metoda lain yang bisa dikembangkan. Metode yang lebih mudah, nyaman dan murah adalah penggunaan coldpack instan. Namun, penelitian mengenai cold-pack instan dalam menurunkan suhu tubuh pasien cedera kepala belum diketahui dengan jelas. Metoda selimut basah belum terbukti efektif dalam penelitian, serta belum ada standar prosedurnya. Oleh karena itu, peneliti tertarik untuk meneliti perbedaan kompres selimut basah dan cold-pack terhadap suhu tubuh pasien cedera kepala di ruang NCCU Rumah Sakit Hasan Sadikin.

Melihat kondisi yang telah dipaparkan sebelumnya bahwa hanya metoda selimut dingin yang biasa dilakukan di NCCU, padahal masih ada metoda lain yang bisa dikembangkan. Metode yang lebih mudah, nyaman dan murah adalah penggunaan coldpack instan. Namun, penelitian mengenai cold-pack instan dalam menurunkan suhu tubuh pasien cedera kepala belum diketahui dengan jelas. Sedangkan metoda selimut basah belum terbukti efektif dalam penelitian, serta belum ada standar prosedurnya. Oleh karena itu, peneliti tertarik untuk meneliti perbedaan kompres selimut basah dan coldpack terhadap suhu tubuh pasien cedera kepala di ruang NCCU Rumah Sakit Hasan Sadikin.

Penelitian ini bertujuan untuk mengetahui perbedaan penurunan suhu tubuh setelah dilakukan kompres dengan menggunakan selimut basah dibandingkan dengan coldpack pada pasien cedera kepala yang mengalami peningkatan suhu tubuh di ruang NCCU Rumah Sakit Hasan Sadikin.

\section{Metode Penelitian}

Penelitian ini merupakan penelitian kuantitatif dengan menggunakan perbandingan tidak berpasangan. Perlakuan yang dilakukan pada penelitian ini adalah kompres selimut basah dan cold-pack pada pasien cedera kepala yang mengalami peningkatan suhu tubuh dengan kriteria inklusi pasien cedera kepala sedang dan berat, pasien mengalami peningkatan suhu tubuh (38-39,9 0C), berjenis kelamin laki-laki dengan usia 18 sampai 60 tahun dengan berat badan $50-70 \mathrm{~kg}$. Kriteria eksklusi untuk sampel pada penelitian ini adalah apabila pasien mengalami dehidrasi sebelum dilakukan kompres, pasien dengan kondisi hemodinamik tidak stabil, pasien mengalami gangguan hormon tiroid.

Kelompok pertama dilakukan kompres 
Sri Hartati: Perbedaan Efek Kompres Selimut Basah dan Cold-pack

dengan menggunakan selimut basah sebagaimana yang sering dilakukan di ruang NCCU, sedangkan pada kelompok kedua dilakukan kompres cold-pack. Evaluasi yang dilakukan dengan melakukan pengukuran suhu tubuh setelah 20 menit dilakukan kompres. Bagan berikut ini menunjukkan rancangan penelitian yang akan digunakan. Rancangan Penelitian

Data pada penelitian ini diperoleh dengan

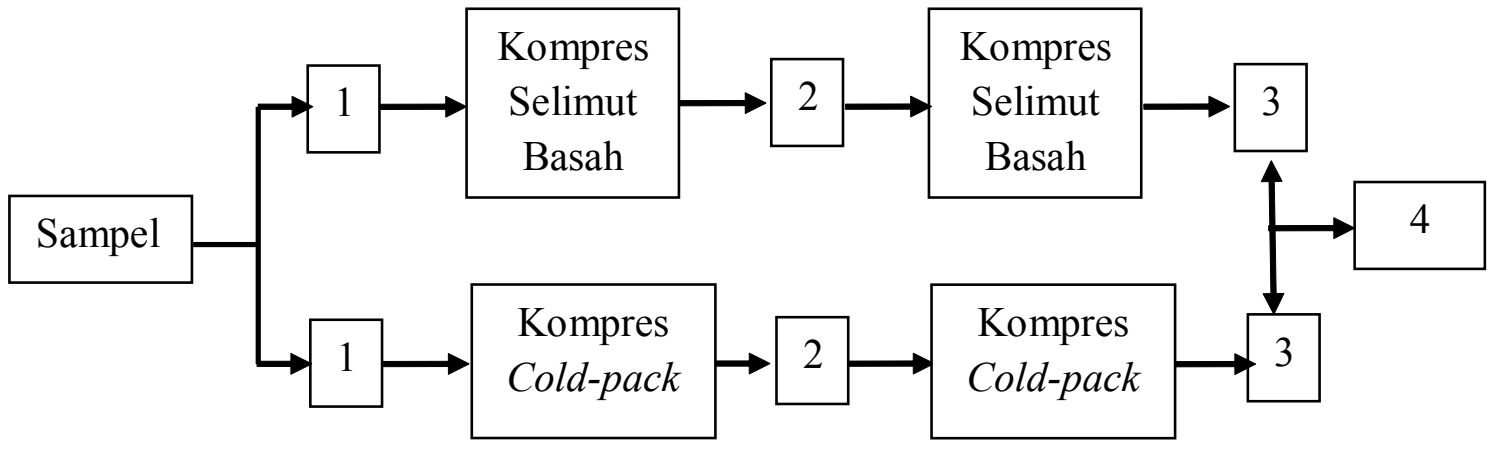

Gambar 1 Rancangan Penelitian

Keterangan:

$\begin{array}{ll}1 & \text { : Pengukuran Suhu Tubuh Awal } \\ 2 & \text { : Pengukuran setelah } 10 \text { menit intervensi (evaluasi 1) } \\ 3 & \text { : Pengukuran setelah } 20 \text { menit intervensi (evaluasi 2) } \\ 4 & \text { : Perbedaan penurunan suhu tubuh }\end{array}$

menggunakan lembar observasi. Lembar observasi tersebut terdapat beberapa bagian yang akan diisi diantaranya adalah suhu dan respon tubuh responden. Lembar observasi diisi pada sepuluh menit pertama dan sepuluh menit kedua. Data suhu tubuh pasien didapat dengan melakukan pemeriksaan suhu tubuh dengan termometer timpani bermerk Clever TD-1116. Alat yang digunakan untuk melakukan kompres adalah cold-pack pada kelompok pertama dan selimut basah pada kelompok kedua. Cold-pack merupakan alat kompres instan berisi gel yang bisa digunakan untuk kompres dingin dan panas, namun dalam hal ini kompres dingin yang digunakan. Cold-pack digunakan dengan diselimuti kain waslap terlebih dahulu. Sedangkan kompres dengan selimut basah, menggunakan handuk yang dibasahi air suhu ruangan $\left(23-25^{\circ} \mathrm{C}\right)$. Pengumpulan data dilakukan setelah melalui proses seminar usulan penelitian dan mendapatkan surat ijin serta ethical clearance dari Komite Etik Fakultas Kedokteran Universitas Padjadjaran.

\section{Hasil Penelitian}

Perbedaan Suhu Tubuh Sebelum dan Sesudah Kompres Selimut Basah

Sebelum dilakukan analisa perbedaan suhu tubuh, dilakukan analisa normalitas data dengan menggunakan uji Shapiro-Wilk. Hasil uji normalitas data suhu awal responden kelompok kompres selimut basah adalah $p$ $=0,199$, suhu 10 menit pertama dengan $\mathrm{p}=$ 0,274 dan $p$ data suhu setelah 20 menit adalah 0,235 . Dari semua data tersebut didapatkan hasil $\mathrm{p}>0,05$ sehingga dapat disimpulkan bahwa data suhu responden kelompok selimut basah berdistribusi normal. Perbedaan suhu tubuh sebelum dan sesudah kompres selimut basah dapat dilihat dari tabel 1 .

Berdasarkan tabel 1 dapat dilihat bahwa suhu tubuh responden sedikit turun menjadi $38,59^{\circ} \mathrm{C}$ dengan simpang baku $0,67^{\circ} \mathrm{C}$ pada evaluasi 1 dan $38,48^{\circ} \mathrm{C}$ dengan simpang baku $0,07{ }^{\circ} \mathrm{C}$ pada evaluasi 2 . Secara statistik terdapat perbedaan yang bermakna antara suhu tubuh sebelum dan setelah dilakukan kompres selimut basah $(p=0,000)$. 
Sri Hartati: Perbedaan Efek Kompres Selimut Basah dan Cold-pack

Tabel 1 Perubahan Suhu Tubuh Responden Kelompok Kompres Selimut Basah

\begin{tabular}{llcccc}
\hline \multicolumn{2}{c}{ Evaluasi Suhu Tubuh } & $\mathbf{x}(\mathbf{0 C})$ & Sd & t & P \\
\hline Evaluasi 1 & Suhu Awal & 38.64 & 0.65 & 3.317 & 0.007 \\
& Suhu 10' pertama & 38.59 & 0.67 & & \\
Evaluasi 2 & Suhu Awal & 38.64 & 0.65 & \multirow{2}{*}{6.092} & 0.000 \\
& Suhu 10' kedua & 38.48 & 0.07 & & \\
\hline
\end{tabular}

Tabel 2 Perubahan Suhu Tubuh Responden Kelompok Kompres Cold-pack

\begin{tabular}{llcccc}
\hline \multicolumn{2}{c}{ Evaluasi Suhu Tubuh } & $\mathbf{x ~ ( 0 C )}$ & Sd & t & P \\
\hline \multirow{2}{*}{ Evaluasi 1 } & Suhu Awal & 38.79 & 0.87 & 4.690 & 0.001 \\
& Suhu 10' pertama & 38.72 & 0.86 & & \\
Evaluasi 2 & Suhu Awal & 38.79 & 0.87 & \multirow{2}{*}{8.373} & 0.000 \\
& Suhu 10' kedua & 38.60 & 0.80 & & \\
\hline
\end{tabular}

Tabel 3 Perbedaan Penurunan Suhu Tubuh Responden Kelompok Kompres Selimut Basah dengan Cold-pack

\begin{tabular}{|c|c|c|c|c|c|c|}
\hline \multirow[t]{3}{*}{ Evaluasi } & \multicolumn{4}{|c|}{ Perubahan Suhu } & \multirow[t]{3}{*}{$\mathbf{t}$} & \multirow[t]{3}{*}{$p$} \\
\hline & \multicolumn{2}{|c|}{ Selimut Basah } & \multicolumn{2}{|c|}{ Cold-pack } & & \\
\hline & Rerata & $\begin{array}{c}\text { Standar } \\
\text { Deviasi }\end{array}$ & Rerata & $\begin{array}{c}\text { Standar } \\
\text { Deviasi }\end{array}$ & & \\
\hline Evaluasi 1 & 0.05 & 0.05 & 0.07 & 0.04 & 0.790 & 0.237 \\
\hline Evaluasi 2 & 0.16 & 0.09 & 0.19 & 0.07 & 0.914 & 0,371 \\
\hline
\end{tabular}

Perbedaan suhu tubuh sebelum dan sesudah kompres cold-pack, dapat dilihat hasil uji normalitas data suhu awal responden kelompok cold-pack dilakukan dengan uji Shapiro-Wilk $\mathrm{p}=0,589$ adalah $\mathrm{p}$ suhu 10 menit pertama 0,485 , dan $\mathrm{p}$ suhu setelah 20 menit adalah 0,591. Semua hasil uji normalitas tersebut didapatkan hasil $p>0,05$ sehingga dapat disimpulkan bahwa data suhu responden kelompok cold-pack berdistribusi normal. Perbedaan suhu tubuh sebelum dan sesudah kompres cold-pack dapat dilihat bahwa suhu tubuh responden pada evaluasi 1 menjadi $38,72^{\circ} \mathrm{C}$ dengan simpang baku $0,87^{\circ} \mathrm{C}$ dan $38,60^{\circ} \mathrm{C}$ dengan simpang baku $0,8^{\circ} \mathrm{C}$ pada evaluasi 2. $\mathrm{p}$ yang dihasilkan dari uji t berpasangan adalah 0,000 sehingga dapat disimpulkan terdapat perbedaan yang bermakna antara suhu tubuh sebelum dan sesudah kompres cold-pack secara statistik (Tabel 2).

Perbedaan penurunan suhu tubuh responden kelompok kompres selimut basah dan cold-pack, dapat dilihat penurunan suhu tubuh responden kelompok selimut basah $0,16^{\circ} \mathrm{C}$ dengan simpang baku 0,09 . Penurunan suhu tubuh responden kelompok kompres cold-pack sebesar $0,19^{\circ} \mathrm{C}$ dengan simpang baku 0,07. Berdasarkan hasil uji t tidak berpasangan yang dilakukan didapatkan hasil $p=0,371$. Hal ini dapat disimpulkan tidak terdapat perbedaan yang bermakna antara penurunan suhu tubuh responden pada kedua kelompok perlakuan (Tabel 3).

\section{Pembahasan}

Penanganan peningkatan suhu tubuh dapat dilakukan dengan metode farmakologis dan metode pendinginan. Metode pendinginan dari luar dapat dilakukan dengan berbagai cara diantaranya adalah kompres. Metoda pendinginan pada pasien cedera kepala lebih banyak menggunakan prinsip konduksi (Thompson, Mitchell, \& Webb, 2007). Kompres yang dilakukan dalam penelitian ini adalah kompres selimut basah dengan 
Sri Hartati: Perbedaan Efek Kompres Selimut Basah dan Cold-pack

menggunakan handuk yang dibasahi dengan air suhu kamar, kemudian diselimutkan di atas dada dan perut responden. Metoda ini menggunakan prinsip konduksi dan evaporasi. Melalui kedua metode tersebut, panas dari tubuh responden dapat pindah ke selimut basah. Selain itu, evaporasi diharapkan bertambah karena air yang terkandung dalam selimut basah dapat memperantarai perpindahan panas ketika air berubah menjadi gas. Konduksi terjadi antara suhu selimut basah dengan jaringan sekitarnya termasuk pembuluh darah sehingga suhu darah yang melalui area tersebut akan menurun. Kemudian darah tersebut akan mengalir ke bagian tubuh lain dan proses konduksi terus berlangsung sehingga setelah dilakukan kompres dengan selimut basah, suhu tubuh pasien dapat menurun. Hal ini didukung oleh penelitian Morgan dalam Axelrod (2000), metoda pendinginan selimut dingin lebih cepat menurunkan panas pada pasien cedera kepala dibandingkan dengan metoda tepid-water sponge. Hal ini sesuai dengan penelitian yang dilakukan oleh Henker (1999) yang menyatakan bahwa penanganan peningkatan suhu tubuh dengan memberikan acethaminophen dan metode pendinginan lebih efektif dibandingkan dengan pemberian obat atau metode pendinginan saja.

Selimut basah merupakan modifikasi dari kompres konvensional yang diletakkan di atas dada dan perut responden. Penelitian sebelumnya yang telah dilakukan mengenai efektivitas kompres konvensional adalah penelitian Hoedemaekers, Ezzahti, Gerritsen, dan Hoeven (2007). Penelitian ini membandingkan berbagai metoda pendinginan untuk menurunkan suhu tubuh pasien di ICU sampai mencapai suhu tubuh normal dan memberikan hasil yang tidak jauh berbeda dimana kecepatan penurunan suhu dengan metoda ini adalah $0,31^{\circ} \mathrm{C} / \mathrm{jam}$ $\left(0,055^{\circ} \mathrm{C} / \mathrm{min}\right)$.

Penurunan suhu dari penelitian ini adalah $0,158^{\circ} \mathrm{C} \pm 0,09^{\circ} \mathrm{C}$ dalam 20 menit. Jika dibandingkan dengan penelitian Hoedemaekers, Ezzahti, Gerritsen, dan Hoeven(2007), penurunankecepatankompres selama 20 menit adalah $0,1^{\circ} \mathrm{C}$. Disimpulkan bahwa hasil penelitian ini tidak jauh berbeda dengan penelitian tersebut. Sedikit perbedaan penurunan ini dapat dipengaruhi oleh adanya perbedaan metoda yang digunakan. Selimut basah dapat membantu proses evaporasi dibandingkan dengan kompres es biasa.

Meskipun terjadi penurunan suhu tubuh pada responden setelah dilakukan kompres selimut basah, namun suhu tubuh responden masih diatas normal. Hal ini bisa dikarenakan berbagai faktor diantaranya yaitu waktu (Hoedemaekers, Ezzahti, Gerritsen, \& Hoeven, 2007). Waktu yang digunakan untuk pengompresan hanya 20 menit, jika dilakukan lebih dari itu dimungkinkan masih terjadi penurunan suhu. Hal ini dapat dilihat dari evaluasi pertama dan kedua, dimana suhu tubuh responden semakin menurun pada evaluasi kedua. Sehingga dapat disimpulkan semakin lama waktu yang digunakan untuk pengompresan, penurunan suhu tubuh dimungkinkan akan semakin bertambah.

Cold-pack merupakan alat kompres instan yang bisa digunakan untuk kompres panas maupun dingin yang dapat digunakan berulang kali. Alat ini terbuat dari gel ammonium nitrat yang tidak beracun. Gel ammonium nitrat dapat memelihara suhu tetap dingin dalam jangka waktu yang lama dibandingkan dengan zat lain. Cold-packyang telah didinginkan diharapkan dapat menyerap panas tubuh melalui prinsip konduksi yang terjadi antara cold-pack dengan jaringan di sekitarnya termasuk pembuluh darah. Suhu darah yang mengalir melalui pembuluh darah disekitar area pengompresan akan menurun karena proses konduksi yang terjadi dengan suhu cold-pack.

Cold-pack merupakan modifikasi dari kompres es dan kompres air dingin. Gel ammonium nitrat yang ada di dalam coldpack memiliki fungsi yang sama dengan es dan air dingin tanpa membasahi bagian tubuh responden. Penelitian sebelumnya yang telah dilakukan mengenai kompres es adalah penelitian yang dilakukan oleh Hoedemaekers, Ezzahti, Gerritsen, dan Hoeven (2007). yang menyimpulkan bahwa kompres es merupakan salah satu kompres konvensional yang dapat menurunkan suhu tubuh dengan kecepatan $0,31^{\circ} \mathrm{C} / \mathrm{jam}$ sehingga apabila kompres dilakukan selama 20 menit maka penurunan suhu akan mencapai $0,1^{\circ} \mathrm{C}$. Tidak jauh dengan penelitian tersebut, kompres dengan menggunakan cold-pack selama 20 menit dapat menurunkan suhu 
Sri Hartati: Perbedaan Efek Kompres Selimut Basah dan Cold-pack

tubuh sekitar $0,196^{\circ} \mathrm{C}$.

Selimut basah dan cold-pack merupakan salah satu metode pendinginan yang banyak dilakukan. Penelitian ini, perbandingan efek kompres selimut basah dan coldpack dilakukan dengan membandingkan penurunan suhu yang terjadi setelah kompres. Dilakukan uji statistik t tidak berpasangan, didapatkan hasil tidak ada perbedaan yang bermakna antara penurunan suhu tubuh setelah dilakukan kompres selimut basah dengan cold-pack $(\mathrm{p}=0,371)$. Hal ini dapat disebabkan oleh adanya persamaan mekanisme pengeluaran panas dari kedua metode ini yaitu dengan menggunakan prinsip konduksi. Konduksi berjalan dengan darah di pembuluh darah di sekitar area pengompresan. Darah tersebut akan mengalir ke bagian tubuh lain dan proses konduksi berjalan terus sehingga suhu tubuh akan menurun. Meskipun luas cold-pack hanya $2,9 \%$ dari luas selimut basah namun cold-pack memiliki suhu yang lebih rendah. Cold-pack memiliki suhu sekitar $15-18^{\circ} \mathrm{C}$, sedangkan selimut basah $18-27^{\circ} \mathrm{C}$. Sehingga proses konduksi berjalan seimbang. Selain itu kedua metode tersebut memiliki persamaan lain yaitu metode pendinginan dari luar sehingga konduksi yang terjadi sebagian besar akan mempengaruhi suhu perifer dibandingkan dengan suhu inti (Tranter, 2011). Oleh karena itu, laju penurunan suhu tidak jauh berbeda.

Hasil penelitian ini menunjukkan bahwa metode kompres selimut basah yang biasa digunakan memiliki efek yang sama terhadap penurunan suhu tubuh pasien cedera kepala dengan kompres cold-pack. Oleh karena itu, kompres dengan menggunakan coldpack dapat dijadikan alternatif dalam pemberian metode pendinginan. Metode kompres selimut basah tidak membutuhkan biaya, perawat hanya memerlukan handuk dan air bersuhu ruangan. Namun, air yang terkandung dalam selimut basah cenderung turun ke bawah sehingga menyebabkan linen menjadi lembab dan basah. Hal ini dapat menimbulkan ketidaknyamanan pada pasien dan dapat menimbulkan tumbuhnya jamur. Metode ini dapat menyebabkan bagian belakang tubuh pasien bertambah lembab sehingga dapat meningkatkan resiko dekubitus.

Berbeda dengan selimut basah, kompres dengan menggunakan cold-pack tidak menimbulkan basah pada linen pasien. Hal ini berkaitan dengan area kompres yang lebih sedikit dibandingkan dengan selimut basah. Oleh karena itu, metoda kompres ini tidak meningkatkan resiko dekubitus sehingga kondisi pasien tidak menjadi lebih buruk dan pertambahan lama hari rawat karena dekubitus tidak terjadi. Selain itu, pasien tidak perlu mengeluarkan biaya tambahan untuk perawatan luka dekubitus. Dalam penggunaannya, cold-pack dibungkus dengan menggunakan kain sehingga lebih dirasakan nyaman oleh pasien. Keuntungan bagi pihak Rumah Sakit, kompres cold-pack lebih mudah dikerjakan karena perawat tidak perlu sering mengganti cold-pack sehingga tidak menambah beban kerja. Selain itu, dengan berkurangnya resiko dekubitus dapat meningkatkan mutu pelayanan.

\section{Simpulan}

Simpulan dari penelitian ini adalah secara statistik tidak terdapat perbedaan yang bermakna antara penurunan suhu responden yang mendapatkan kompres selimut basah dengan kompres cold-pack. Perbedaan penurunan suhu tubuh setelah kompres menggunakan cold-pack lebih dari 20\% penurunan suhu setelah kompres selimut basah sehingga bermakna secara klinis.

Hasil penelitian ini membuktikan bahwa tidak ada perbedaan yang bermakna antara penurunan suhu pasien yang diberikan kompres cold-pack dan selimut basah yang biasa dilakukan diruangan, sehingga kompres menggunakan cold-pack dapat dijadikan alternatif pemberian metode pendinginan pada pasien cedera kepala yang mengalami hipertermia. Kompres cold-pack tidak menimbulkan efek basah sebagaimana selimut basah sehingga lebih nyaman untuk pasien selain itu lebih mudah dilakukan oleh perawat.

Hasil penelitian ini diharapkan dapat dijadikan data dasar bagi penelitian selanjutnya mengenai metode lain yang lebih efektif dalam menurunkan suhu tubuh pasien dengan memperhatikan kenyamanan dan keamanan bagi pasien. Selain itu, hasil penelitian ini diharapkan dapat menjadi dasar 
Sri Hartati: Perbedaan Efek Kompres Selimut Basah dan Cold-pack

penelitian selanjutnya mengenai metoda yang sama tetapi dengan waktu dan jumlah yang berbeda.

\section{Daftar Pustaka}

Agrawal, A., Timothy, J., \& Thapa, A. (2007). Neurogenic Fever. Singapore Medicine Journal, 48, 492-494. Melalui http://smj. sma.org. Diakses pada tanggal 4 Maret 2012.

Axelrod, P. (2000). External Cooling in the Management of Fever. The Infectious Disease Society of America, 31, 224-229. Melalui http://cid.oxfordjournals.org. Diakses pada tanggal 28 Februari 2012.

Badan Penelitian dan Pengembangan Kesehatan Departemen Kesehatan Republik Indonesia. (2007). Laporan Tahunan Riset Kesehatan Dasar Tahun 2007. Diakses pada tanggal 28 Maret 2012.

Diringer, M.N., Reaven, N. L., Funk, S. E., \& Uman, G.C. (2004). Elevates Body Temperature Independently Contributes to Increased Length of Stay in Neurologic Intensive Care Unit Patients. Critical Care Medicine 32, 1489-1495.

Geffroy, A., Bronchard, R., Merckx, P., Seince,P.F., Faillot,T., Albaladejo,P., et al. (2003). Severe Traumatic Head Injury in Adults: Which Patients are at risk of Early Hyperthermia. Intensive Care Medicine, 30, 785-790.

Henker, R. (1999). Evidence Based Practice : Fever - Related Interventions. American Journal of Critical Care, 8, 481-487. Melalui http://www.ncbi.nlm.nih.gov/. Diakses pada tanggal 28 Februari 2012.

Hoedemaekers, C.W., Ezzahti, M., Gerritsen, A., \& Hoeven, J.G. (2007). Comparison of Cooling Methods to Induce and Maintain Normo and Hypothermia in Intensive Care Unit Patients : a Proppective Intervention Study. Melalui http://ccforum.com. Diakses pada tanggal 28 Januari 2012.

Khorooshi, M. H. \& Jensen, N.E. (1999). Cooling of The Brain Through Oxygen Flushing of The Nasal Cavities in Intubated Rats: an Alternative Model for Treatment of Brain Injury. Exp Brain Res, 130, 244-247, doi:10.1007/s002219900230..

Larrson, I.M., Wallin,E., \& Rubertsson, S. (2010). Cold Saline Infusion and Ice Packs Alone are Effective in Inducing and Maintaining Therapeutic Hypothermia After Cardiac Arrest. Resuscitation, 81, 15-19 doi: 10.1016/j.resuscitation.2009.09.012.

Mcilvoy, L. (2007). The Impact of Brain Temperature and Core Temperature on Intracranial Pressure and Cerebral Perpusion Pressure. Journal Neuroscience Nurses, 39, 324-331. Melalui http://www.ncbi.nlm.nih. gov. Diakses pada tanggal 28 Februari 2012.

Muttaqin. (2008). Buku Ajar Asuhan Keperawatan dengan Gangguan Sistem Persyarafan. Jakarta: Salemba Medika.

Thompson,H. J., Tkacs, N. C., Saatman, K .E., Raghupathi, R. \& McIntosh,T.K. (2003). Hyperthermia Following Traumatic Brain Injury: a Critical Evaluation. Neurobiology of Disease, 12, 163-173.

Thompson, H.J., Mitchell, P.H., \& Webb,D.J. (2007). Fever Management Practices of Neuroscience Nurses : National and Regional Perspectives. Journal Neuroscience Nurses. 39, 151-162. Melalui http://www.ncbi.nlm. nih.gov/. Diakses pada tanggal 28 Februari 2012.

Tranter, S.W. (2011). Improving EvidenceBased Care for Patients with Pyrexia. Nursing Standard, 25, 37-41. Melalui http://www. ncbi.nlm.nih.gov/. Diakses pada tanggal 1 Maret 2012.

Werner, C. and Engelhard, K. (2007). Pathophysiology of Traumatic Brain Injury. British Journal of Anaesthesia, 99, 4-9. 